\title{
The Staging of a Scene: Feminist Politics in Jogo de Cena (2007) \& The Arbor $(2010)^{*}$
}

Patrícia Sequeira Brás**

\begin{abstract}
In this article I propose to examine the use of first-person testimonies and their re-enactments in Jogo de Cena (Eduardo Coutinho, 2007) and The Arbor (Clio Barnard, 2010). Through a careful comparison between these two films, I will argue that reenactment complicates the employment of first person testimonies, producing duplicity and a feeling of estrangement in the viewer. Rather than indicating the ambiguous distinction between reality and fiction, re-enactment presupposes instead the staging of a scene of co-appearance.
\end{abstract}

Keywords: Testimony, Re-enactment, Jogo de Cena, The Arbor.

* Received December 13 2019, accepted October 302020.

** Lecturer in Portuguese Studies, Birkbeck, London University, London, U.K. patricia.sequeira.braz@gmail.com/ ORCID: 0000-0002-4756-1150 
A encenação de uma cena: política feminista em Jogo de Cena e The Arbor

\section{Resumo}

Neste artigo proponho analisar o uso do testemunho e da encenação em Jogo de Cena (Eduardo Coutinho, 2007) e The Arbor (Clio Barnard, 2010). Em ambos os filmes, a encenação produz duplicidade e distanciamento. No entanto, a forma como a encenação complica o uso do testemunho significa mais do que uma simples e equívoca diferença entre realidade e ficção. Nestes filmes, a encenação pressupõe uma cena de co-aparência.

Palauras-chave: Testemunho, Encenação, Jogo de Cena, The Arbor. 
Following her experience in consciousness-raising feminist groups in the 1970s in Italy, philosopher Adriana Cavarero argues that feminist practices of storytelling are capable of nurturing "reciprocal narrations" that expose the self to others. In turn, these reciprocal narrations imply a mutual recognition. This is an argument close to Judith Butler's notion of co-vulnerability as well as Hannah Arendt's meaning of political action. Accordingly, selfnarration potentiates a "scene of appearance" in which we act and speak, and see others acting and speaking (Cavarero, 2000:57). For Cavarero "who each one is, is revealed to others when he or she acts in their presence in an interactive theatre where each is, at the same time, actor and spectator" (2000:22).

According to Arendt, "theater is the political art par excellence" because "it is the only art whose sole subject is man in his relationship to others" (1998:188). What actors and speakers convey when re-enacting the story's plot is less about the "story itself" but instead "the 'heroes' who reveal themselves in it". For Arendt (1998:187),

The specific revelatory quality of action and speech, the implicit manifestation of the agent and speaker is so indissolubly tied to the living flux of acting and speaking that it can be represented and "reified" only through a kind of repetition, the imitation or mimesis.

Theater is however "the political art par excellence" not because of its mimetic capacity but because it "pressuposes an ontological horizon of a plurality of actors and spectators" (Kottman, 2008:101). As I understand it, politics proper has nothing to do with representation but instead with the capacity of a word and deed to "change every constellation" (Arendt, 1998:190). All political action is relational and contingent. The scene of appearance emerges then from relationality; and the prerequisite of such scene is its "fundamental orientation towards a future" (Kottman, 2008:11). Futurity gives further expression to political action since the uniqueness of each of the agents and/or speakers 
is exposed within that scene of appearance in the here-and-now, simultaneously anticipating a future scene. I intend to argue then that in Jogo de Cena and The Arbor, first person testimonies are complicated through the use of re-enactment, and in turn, that reenactment furthers "reciprocal narrations", conjuring a scene that is simultaneously political and feminist.

Before shooting Jogo de Cena, Eduardo Coutinho selected a group of women, inviting them to tell their "real" life stories in front of the camera. These women's testimonies consisting of personal experiences of motherhood, loss and mourning were then re-enacted by actresses, some of them well known to Brazilian audiences, like Fernanda Torres, Marília Pêra and Andréa Beltrão, and others less known. Both original testimonies and reenactments were filmed on the same stage. The testimonies are frequently but not always re-enacted and repeated, leading us, viewers, to mistrust the identity of the speakers whilst the actresses often comment on their own performances or recount personal stories therefore coming out of character.

Clio Barnard uses, on the other hand, "real" life testimonies of British playwright Andrea Dunbar's family and friends. The original testimonies are first recorded, and subsequently re-enacted and lip-synched by female and male actors. This is a similar practice to the technique used in verbatim theatre in which the words of real people are recorded and transcribed and then performed by actors. The voice of the speaker is however slightly out-of-synch with the movement of the actors' lips, causing us to distrust the image. Despite differently conveyed re-enactment is equally deployed in both films. Functioning as a self-reflexive procedure, re-enactment creates duplicity and a feeling of estrangement, frustrating mimetic representation by means of exposing the distance between the speaker and her testimony.

The voicing of personal experiences is conventionally used in documentary films. This practice became broadly employed in direct cinema and cinéma vérité however the act of sharing one's own story was also a feminist practice within consciousness-raising groups in the late 1960s. Popularised in the US, consciousness- 
raising groups contaminated the feminist movement internationally. These groups functioned in opposition to patriarchal social structures; and, in them, women could share their personal and daily life experiences as a means to recognise within these shared stories their subjection to the same power structure despite their individual differences. Films such as, The Woman's Film (Women's Caucus, San Francisco Newsreel: including Louise Alaimo, Judy Smith, Ellen Sorin, 1970) and Scuola Senza Fine (Adriana Monti, 1983) register the ways in which consciousnessraising groups were organised yet the practice of storytelling within these groups have also inspired a comprehensive body of documentary films in the 1970s, in which women tell their stories in front of the camera. This is the case of Brazilian filmmaker Helena Solberg's earliest film The Interview (1966) as well as her films produced in collaboration with the International Women's Film Project after moving to the US; e.g., The Double Day (1975) and Simply Jenny (1977), and also the case of a number of feminist documentary films, such as Janie's Janie (Newsreel: various, including Geri Ashur, Bev Grant, Marilyn Mulford, Stephanie Palewski, Peter Barton, 1970), Growing Up Female (Julia Reichert and Kim Klein, 1971), Three Lives (Kate Millett, Susan Kleckner and Louva Irvine, 1971), Betty Tells Her Story (Liane Brandon, 1972), Joyce at 34 (Joyce Chopra, 1972), and Union Maids (Jim Klein, Julia Reichert and Miles Mogulescu, 1976), among others. ${ }^{1}$

\footnotetext{
${ }^{1}$ In all these films women tell their stories in front of the camera however this procedure results in substantially different outcomes. For instance, when discussing the similarities and differences between Joyce at 34 (1972) and Janie's Janie (1971), E. Ann Kaplan concludes that despite using apparently similar procedures, these two films are substantially different. In the case of the former, the film is autobiographical as the director records her own experience of pregnancy. E. Ann Kaplan argues that Joyce uses her own voice over the image to "suture [...] conflicts and contradictions"; thus, reading the film against the grain, Kaplan argues that Joyce appears "at the mercy of the structures that shaped her" including her class privilege (2000:128). Unlike Joyce at 34, in Janie's Janie, the main character is a working-class woman who provides a firstperson account of how she became fully conscious "of her gendered and class position" in society (Id.ib.).
} 
Film scholars have already addressed relevant questions concerning feminist documentary cinema, particular in the context of British and North-American film production (Rich, 1998; Waldman and Walker, 1999). Some have argued that feminist documentary filmmakers tend to establish different kinds of relationships with their subjects on camera, which enable new ways of thinking about the politics of filmic representation (Lesage, 1978; Martineau, 1984; Rich, 1998); others have discussed extensively autobiography as a subject matter (Kuhn, 1995; Neuman, 1991; Smith and Watson, 1993); and others even, have argued that feminist documentary films were informed by consciousness-raising groups' practices of storytelling when employing "an older form of subcultural resistance, women's conversation"2 (Lesage, 1990:231). Feminist documentarians were committed to critically engage their audiences, using a technique simultaneously informed by oral history and consciousness-raising groups - the "talking-heads" - to overcome the audience's depreciation for experimental film techniques (Michel, 1990:240).

First-person testimonies were often the structuring element of feminist documentaries since in many of these films, we see "ordinary details of women's lives, their thoughts" being told in person to the camera (Kuhn, 1982:148). For Annette Kuhn (1982:148), these films inherited "many of the defining textual features of direct documentary" whereas, for Julia Lesage, feminist documentary filmmakers sought out the aesthetic features of direct cinema because it "demanded a less mastery of the medium" (Lesage, 1990:199). Feminist filmmakers appeared less preoccupied

\footnotetext{
${ }^{2}$ Interestingly, the idea of women's conversation as a subcultural resistance is best understood in view of the concept of the 'gossip'. According to Silvia Federici, the meaning of the word in the middle ages was used to signify women's comradeship however today is use to belittle women. The concept of the gossip is discussed in Federici's recently published book Witches, Witch-hunt, and Women (2019), which revisits the argument exposed in Caliban and The Witch (1998) on how witch-hunt along with land privatization and colonial plunder was instrumental for the foundation of capitalism. In this way, according to Federici, witch-hunt anticipated reproductive control that was imposed on women in compliance to the capitalist demand for labour-power.
} 
with the formal aspects of filmmaking, particularly in the US, because according to E. Ann Kaplan, the feminist movement was characterised by its "sociological theoretical approaches", seeing cinema mostly as a "powerful organizing tool' and therefore less concerned with producing so-called 'aesthetic objects" (2000:126).

Despite inheriting these defining features from direct cinema, feminist documentary film practices have also departed from such aesthetics when women's testimonies and stories began to regulate the film's narrative (Kuhn, 1982:150). In this respect, these films strategically rejected a so-called "neutral" observation, offering instead "a situated truth embedded in a feminist politics founded on an acceptance of the validity of individual experience" (Kuhn, 1982:152). Still, because first-person accounts are often "fragmentary, idiosyncratic, and sometimes - deliberately or unintentionally - misleading", filmmakers were expected to also employ reflexive devises to situate these testimonies "both critically and circumstantially within a larger historical context" (Michel, 1990:242). For some feminist film critics, cinematic realism was too naïve in its assumption of "an unmediated world that somehow we could have access to" (Kaplan, 2000:146). Similarly, Claire Johnston argued that the reality of "our oppression" had to be constructed because the camera is capable of grasping "the "natural' world of the dominant ideology" (1999:214). As a result filmmakers have used sophisticated means to complicate the use of first-person testimony. This is the case of Yvonne Rainer's films, including Film About a Woman Who (1974), Kristina Talking Pictures (1976), Journeys from Berlin/1971 (1980) and Privilege (1990), but also Soft Fiction (Chick Strand, 1979), Que bom te ver viva (Lúcia Murat, 1989), and more recently, Yours in Sisterhood (Irene Lusztig, 2018).

This far-ranging excursion on the long-standing debates concerning the use of a realistic versus a political modernist aesthetic hopes to contextualise the films under analysis within a long tradition of feminist film practices in which testimony is problematized through the use of re-enactment. In the same way, I intend to argue that Jogo de Cena and The Arbor are affiliated 
with a feminist politics that is independent of the intentionality of the authors, and in case of Coutinho, his potential gender bias.

\section{Jogo de Cena (Eduardo Coutinho, 2007)}

Jogo de Cena opens with a newspaper clip calling for women living in Rio de Janeiro with stories to tell. Immediately after the clip, the camera follows a woman going up the stairs to a stage where director Eduardo Coutinho is seating opposite an empty chair. Next to the camera and surrounded by lightning equipment, Coutinho welcomes her: "Hi, Jackie!" With her back turned to the empty seats of the theatre, Jackie addresses the director: "How can I, a Black girl, with no proper education, suddenly become an actress? It's crazy!" At this point, the viewer is forced to attend to all aspects of her social and political identity in which gender, class and race are interconnected thus generating a scene of address. Jackie explains that she began to perform after joining "Nós no morro", a community theatre group based in favela do Vidigal in Rio de Janeiro. She is currently performing Joana, the main character of Gota d'Água (The Last Straw), an adaptation of Euripides' play Medea written by Chico Buarque and Paulo Pontes. Jackie becomes then Joana before the camera, performing the instance in which her character (like Medea) kills her children. The fixed camera enhances the passage of time, and the duration of the scene signals her becoming another through performance. The scene also prefigures the act of performance and the use of re-enactment as the film's subject matter. Even more so, because this Jackie is a double forger re-enacting the testimony of the 'real' Jackie who later in the film raps her own story.

When introducing the concept of "the power of the false" to characterise the crystalline regime of the time-image that emerges with modern cinema, Gilles Deleuze argues that "narration becomes temporal and falsifying at exactly the same time" (1989:132). The time-image ruptures with the sensory motor descriptions found in the organic regime of the movement-image, giving way to "pure optical and sound situations" (1989:130). 
Under the concept of "the power of the false", narration is exempt from the judgement of truth, "and becomes fundamentally falsifying" (Deleuze, 1989:131). In Jogo de Cena, the original and re-enacted testimonies are often interlaced and told twice but there are moments when testimonies are placed apart, preventing the recognition of who is telling her story. In addition, both testimonies and re-enactments are delivered on the same stage without an audience thus the film refuses to submit to a linear conception of time. Montage contributes then to erode "distinctions between reality and performance, juxtaposing and overlaying real and performed memories and experiences" (Page, 2013:74). This erosion is exacerbated either because we cannot distinguish the less known actresses from the women who share their testimonies or because a testimony is not repeated, leaving us viewers, without the terms of comparison to speculate whether the testimony is original or re-enacted. Rather than judging the authenticity of these women's testimonies, Jogo de Cena demands that we recognise this process of becoming another when both actresses and non-actresses "tell stories without ever being fictional" (Deleuze, 1989:150).

From the eighty-three interviews made, Coutinho selected twenty-three testimonies to be recorded in Teatro Glauce Rocha in Rio de Janeiro. Each actress received a copy of a recorded testimony; and, each re-enactment was recorded again on stage. Using conventional talking heads, all women are seating on a chair, facing the director with their backs to the empty seats of the theatre. The fixed camera frames their facial expressions and corporeal presence through medium and close-up shot compositions while we listen to their testimonies.

Since working for Globo Repórter network in the 1970s, the interview became integral to Coutinho's aesthetics. For this reason, many have argued that for him, a film is an encounter, a conversation between interviewer and interviewee since Coutinho privileged above all his relationship with the film subjects (Xavier, 2016; Feldman, 2012). According to Ismail Xavier, Coutinho "developed a minimalist version of the interview-based 
documentary" devoted to "the interaction between camera, filmmaker and interviewed subjects" (2009:211). For Xavier, Coutinho was "engaged in the systematic exploration of what is the medium-specific in the cinematic representation of time, using long takes to capture revealing and unexpected moments of selfenactment" (2009:211). In a similar way, Natália Brizuela argues that "the relationship between conversation and duration, and therefore words and temporality" are "fundamental to Coutinho's films" (2016:19). To support her argument, Brizuela discusses a sequence from Six Days of Ouricuri (1976) in which a man recounts the many types of roots he was forced to eat to survive the drought in sertão. Because Coutinho decides not to edit out "the "excess", the sequence becomes "repetitive"; and "this excess, the 'misuse' of time in normative production terms, [...] delivers the shot to the realm of affect, into the affective being of that particular man" (Brizuela, 2016:19). This highlights Coutinho's ethical commitment to the person in front of the camera, a strategy found also in his later films, including Jogo de Cena, where full attention is given to the women's testimonies as much as to the actresses' performances. As discussed earlier, regarding the scene when Jackie becomes Joana, the interview acquires further significance because of the use of a fixed camera shot that enhances the passage of time. For Brizuela, "speech is nothing unless it is given the time needed by those words emerging through the voice of that particular body at that particular moment which can never be predicted" (2016:21). This point is reminiscent of Cavarero's understanding of the voice's capacity to reveal the uniqueness of each individual, and the role of listening in the emergence of a scene of co-appearance.

In Jogo de Cena, Coutinho addresses the interviewees, guiding their testimonies while the women often return his questions back to him. Although much of the listening takes place off-screen, there is a deliberate choice to render visible and audible this exchange of address. The sound of his voice and his appearance in the shots disclose his bodily presence but also his commitment to attentive listening, which conveys, on the other 
hand, the necessary requirement of someone listening to someone else to create a plural space of mutual recognition that is according to Cavarero the very definition of a political scene.

In addition, by putting into question the ways in which testimonies are mediated through the camera, and as such, staged, Coutinho interrogates his own recurring practice of using firstperson testimonies in his films. But reflexivity is not only found "within the approach of the director" but also in "the filmic subjects" themselves (Page, 2013:74). According to Xavier, this is because of his "camera-effect" that allows "the emergence of that which would not be possible without the presence of the camera" (2009:214). This "camera-effect" is the result of allowing his film subjects the time needed "to gain control of their performance" and in this way, "become the judges of their own false and true utterances" (2009:213). In Jogo de Cena, reflexivity is found then in the "real" testimonies as much as in the actresses' reenactments.

Throughout the film, the actresses often come out of character to comment about their own performance and/or the difficulty of re-enacting someone else's testimony. In one particular testimony, nothing in its delivery suggests that we are watching a re-enactment until the less known actress Débora Almeida looks into the camera to say: "Foi isso que ela disse!" thus breaking with talking head conventions by means of addressing both director and audience.

Later in the film, Gisele tells how she overcame her grief for the death of her baby son after having a dream that made her believe she would continue to be his mother in a spectral reality. Gisele's testimony is interlaced with Andréa Beltrão's reenactment. At the end of the sequence, Beltrão comes out of character stating that although she intended to be faithful to the original she could not prevent herself from crying. Despite empathic, she is incapable of embodying the serenity of her character because unlike Gisele she has no spiritual beliefs.

On the other hand, Sarita's emotional testimony about her relationship with her estranged daughter is interlocked with Marilia 
Pêra's far more restrained performance. Pêra says that she became almost tearful when her own daughter came to her mind but decided to hold back her emotions because when "the feeling is truthful and painful one often tries to hide it". Paradoxically, the actress' emotional inhibition is intended to produce a far more truthful performance despite Sarita's originally unrestrained testimony. Following her request, Sarita resurges on stage to sing because her initial statement was too grave. According to her, the opportunity to record the interview again would allow her to be more buoyant and cheerful thus evidencing that not only actresses but also "real women" judge and reflect upon their own performances (Page, 2013:79). Reminded of her daughter, Sarita cries in her second testimony, demonstrating also that not only "bad" or soap opera actors tend to overstate their feelings, contradicting Pêra's assumption.

The most puzzling sequence takes place when Fernanda Torres re-enacts the testimony of Aletha. Similar to the opening scene of the film, we follow Aletha going up the stairs in direction to the stage. Her entrance on stage is intercalated with Fernanda Torres's performance, who after repeating Aletha's last sentence is prevented to continue since Coutinho interrupts her, calling her "Nanda" and telling that she did exactly like her character. During the interview, the fixed camera slowly registers the actress' struggle to stay in character. Despite the few cuts that compose the sequence, the duration of each shot warrants our scrutiny, thus revealing the almost imperceptible change in her performance when oscillating between herself and her character. Torres comments about the difficulty of performing a non-fictional character as if "reality" was prowling, interrupting her own interpretation, whereas the "real" Aletha is doubtful about the coherence of her own narrative in comparison with her first interview. This perplexing sequence shows both women reflecting upon their own performances. Through duplicity, re-enactment signals then the almost imperceptible distance between the actress and her character while Aletha also reflects upon the authenticity of her own testimony. This suggests that meaning and truth reside 
perhaps in the inconsistencies of our own utterances and in the "dichotomy between person and character, singular and collective, authenticity and performance, memory and the here-and-now" (Feldman, 2012:33).

The Arbor (Clio Barnard, 2010)

For The Arbor, Clio Barnard recorded the "real" life testimonies of British playwright Andrea Dunbar's family and friends. These testimonies were then re-enacted and lip-synched by female and male actors. The movement of the actors' lips are however slightly out-of-synch with the sound of the interviewees' voices, making the words uttered not correspond entirely to the bodies on screen. This technique exposes the distance between actor and testimony creating a sense of strangeness. Synchronous dialogue is, according to Mary Ann Doane, the "dominant form of sonorous representation in the cinema" (1980:35); synchronicity disguises the "work of the apparatus", reducing "the distance between the object and its representation" (1980:35). By using the lip-synching technique - separating voices from the bodies on screen - Barnard appears to expose the work of the cinematic apparatus, deliberately widening the gap "between reality and representation" (James, 2010:25).

Andrea Dunbar grew up in the Buttershaw Estate in Bradford in West Yorkshire. Inspired by her own personal experiences living in a deprived estate, Dunbar wrote her first play The Arbor (1977) at the age of 15. Focusing on issues such as domestic violence, "alcoholism, racial tensions, teenage pregnancy and unemployment (Mello, 2016:118), her play provides a realistic portrait of England under Margaret Thatcher's government. The play was performed in 1980 at the Royal Court Theatre under the direction of Max Stafford-Clark, who would later commissioned Dunbar's second play Rita, Sue and Bob Too (1980). Despite her precocious success, Dunbar died at 29 from brain haemorrhage after years of alcohol addiction. Ten years later Stafford-Clark wrote the verbatim play State Affair (2000) with Robin Soans, 
collecting testimonies from the dwellers of the estate, including Andrea Dunbar's oldest daughter Lorraine. After a series of interviews, Barnard became familiar with Lorraine's tragic story. Following her participation in State Affair, Lorraine was sentenced for the death of her two-year old son Harry, who accidentally overdosed on her prescribed methadone. Through her testimony, Barnard not only problematizes how memories are produced and testimonies registered but also underlines how stories of dispossession and addiction are replicated.

Barnard stresses upon the repetitive nature of these stories by using Buttershaw Estate as a background. Initially she envisioned her project as a part of a trilogy about the estate after Dunbar and Stafford-Clark's plays because unlike "a play or a film [...] places don't have endings, they continue" (James, 2010:25). Her focus on the estate is evidenced in the carefully intertwining of the lip-synched audio interviews with the use of contemporary footage, the use of television footage of Dunbar's interviews and her family on site and the re-enactment of Dunbar's first play in Brafferton Arbor, where the playwright used to live, and witnessed by an audience composed of the estate's dwellers.

The film opens with Lorraine telling that despite remembering many of her childhood memories, none of them were good. She continues by telling an important episode of her childhood yet her testimony diverges from her sister Lisa's. Lorraine tells that as a child she set the room on fire when trying to keep her siblings warm while her mother was in the room next door. According to Lorraine, Andrea used to lock up the children by taking the handle out from the door in order to write. Lisa confirms this traumatic event but claims that the door handle fell off instead when she attempted to open the door. These two different accounts problematize the ways in which memories are produced, and throughout the film, we come to understand that these different memories instantiate the different relationships each daughter had with their mother. The strange circumstances of this episode are further "enhanced by the uncanny impression of the 
lip-synching technique" (Mello, 2016:121) that despite subtle is not unnoticed.

Later in the film, Lorraine reads her testimony from the verbatim play State Affair on an empty stage. In the audience we see Andrea Dunbar smoking a cigarette. This is a found-footage of Dunbar that is overlapped with the performance of actor Manjinder Virk lip-synching Lorraine's testimony, disclosing her resentment towards her mum:

One night, when she thought I was asleep, I heard her say she wished she'd had an abortion with me. How could she say that? Every day I feel hurt, pain, anger, hate. That's why I went on heroin... to block out those feelings.

Besides Dunbar, the actors that interpret Lorraine's siblings Lisa and Andrew and Andrea's partner are also in the audience. They disapprove of Lorraine's testimony and Lisa accuses her sister of blaming their mum for her drug addiction.

In relation to Jogo de Cena, Joanna Page argues that the relationship between 'real' and re-enacted testimonies suggests that "truth [...] does not reside, or uniquely reside in the embodied experience of certain individuals' but instead in the 'realm of intersubjectivity" (2013:80). Likewise, in The Arbor, the abovementioned sequence exposes the difference between one's embodied experience and the other's narration of one's story rather than questioning the veracity of any of the testimonies. Here, in this sequence, duplicity is found in the agonistic testimonies however the out-of-synch lip movements and the employment of Dunbar's found-footage also produce a feeling of estrangement in the viewer.

In a different way, estrangement is also experienced when taking notice of the subtle transition of actress Fernanda Torres coming in and out of character in Jogo de Cena. Still, in The Arbor, lip-synching is used as a distancing technique because it dissociates the actor from the character portrayed. Because the actors address directly the camera while lip-synching, Cecilia Mello 
argues that the film appears to generate "empathy" thus posturing "a conundrum to the Brechtian-inflected aesthetics which refuse identification as politically backward" (2016:126).

Brecht's de-dramatization or the alienation effect is meant to taint the viewer's emotional immersion with the play and/or with the characters of the play. The idea that empathy was entirely repudiated in Brecht's Epic Theatre is however incorrect. In the "Appendices of the Short Organum" Brecht claims that "selfidentification with the character should be avoided in the performance" yet this is impossible to be carried out fully (1964:277). Because of this, the actor's performance should aim instead "that truly rending contradiction between experience and portrayal, empathy and demonstration, justification and criticism" (1964:277). In this way, the actor's performance fuses "two mutually hostile processes" (Brecht, 1964:278), which is to say that the performance is a dialectical relation between two processes. This dialectical image at the core of the actor's performance is better understood in a passage of "A Short Organum for the Theatre" in which Brecht probes "where is the man himself, the living, unmistakable man, who is not quite identical with those identified with him? It is clear that his stage image must bring him to light, and this will come about if this particular contradiction is recreated in the image" (1964:191). The distancing or alienation technique serves to expose the distance between actor and character, and between "living man' and its representation in order to rupture with traditional social representations, and create new 'representations of human social life" (Brecht, 1964:185). The distancing technique emerges then from a dialectical tension between actor and character, and between "living man" and its representation.

Contrary to Mello's argument, the problem isn't identification as such, but the ways in which empathy and identification may conceal the contradictions of our own reality. Still, Mello concludes that despite our empathic engagement, the constructed nature of the characters remains "exposed, putting the spectator into a critical thus distanced position in relation to what is 
being told" (2016:126). This is achieved through the use of the lipsynching technique that exposes the distance between on-screen bodies and the words uttered. Empathy is however in a dialectical tension with demonstration therefore part and parcel of the alienation technique. As Dana B. Polan points out, "Brecht's theory of art embodies two identifications: one empathetic and unquestioning - the one connected to the reified vision of the world - and a critical one - a new perspective of knowledge from which the old way is scrutinized" (1974). It is this dialectical tension between empathy and demonstration, between an empathic engagement and a critical one that was crucial for Brecht in order to inspire an ethical and political response from the audience. In Jogo de Cena, this tension is found in the inconsistencies and ambivalences of the original testimonies as well as in the actresses' performances. In Barnard's film, this tension is found instead in the out-of-synch movement of the lips of the actors with the voices from the original testimonies, and the ways in which these testimonies contradict each other.

According to Kaja Silverman, "the rule of synchronization must be understood as referring above all to the smooth alignment of the human form with the human voice - i.e., to the representation of a homogenous thinking subject whose exteriority is congruent with its interiority" (1999:310) therefore the employment of lip-synching - separating the voice and the body on screen - is capable of shattering our expectations of congruency and the idea of a homogenous thinking subject. Moreover, Silverman argues that in cinema the female subject "is [often] constructed precisely as body" (1999:313) whereas the male subject "finds his most ideal realization when he is heard but not seen" (1999:312). Because of this, "feminist cinema has focused an enormous amount of attention on the female voice" (Silverman, 1999:314) and used non-synchronization to divorce the woman's voice from her body, and to reject a female subjectivity that is only constituted through the body.

Regarding The Arbor, radio broadcaster Philip Dodd probes why were working-class Northern women "not good enough to be 
seen"? (Peirse, 2016:2) Following Silverman's argument closely, I suggest that it is not the case that working-class women cannot be seen but instead they can only be heard and 'speak for themselves' (Id.ib.) once their identities are construed through their voices rather than through their on-screen bodies. For this reason, I argue that in Barnard's film, lip-synching divorces the original testimonies from the bodies of the actors in front of the camera to give voice to the experiences of working class women living in the estate, including Dunbar, her daughters and the women that inspired most of the characters in her plays.

In the films under analysis re-enactment complicates firstperson testimonies. In Jogo de Cena, on the one hand, actresses re-enact the original testimonies of women who share their personal experiences of motherhood and mourning. In doing so, the actresses come out of character to comment about their own performances whereas the "real" women judge the veracity of their own utterances due to the presence of the camera. In The Arbor, on the other hand, the original testimonies are instead lip-synched by actors. This technique separates however the original testimonial voices from the on-screen bodies thus producing a feeling of estrangement.

In relation to Close Up (Abbas Kiarostami, 1990), Ivone Margulies argues that re-enactment serves "to sift through and set in relief the fluid, social dimensions of individual identity" (2019:2). Similarly, in Jogo de Cena and The Arbor first-person testimonies are problematized through the use of re-enactment in order to bring to the foreground the social elements inherent to each particular individual. The voicing of personal experiences is conventionally used in documentaries however in these films, the original testimonies are re-enacted. Re-enactment implies then the transformation of these first-person accounts into reciprocal narrations. As such, I argue that these reciprocal narrations potentiate the emergence of a "scene of appearance" in which both actors and speakers "reveal themselves in it" (Arendt, 1998:187). The singular identities of speakers and actors overlapp but never entirely coincide. For this reason, re-enactment appears 
to underline rather than undermine the uniqueness of these voices and stories, producing a '"web' of human relationships", understood here, as the staging of a political scene (Arendt, 1998:183).

\section{References}

ARENDT, Hannah. The Human Condition. London/Chicago, University of Chicago Press, 1998.

BRECHT, Bertolt. A Shot Organum for the Theatre. Brecht on Theatre: The Development of an Aesthetic. In: WILLET, J. (ed \& trans). New York, Hill \& Wang, 1964, pp.179-206.

BRIZUELA, Natália. Conversation and Duration in Eduardo Coutinho's Films. Film Quarterly, vol. 69, n. 3, pp.19-27 [https://filmquarterly.org/2016/03/04/conversation-and-duration-ineduardo-coutinhos-films/ - accessed 18 May 2019]

CAVARERO, Adriana. Relating Narratives: Storytelling and Selfhood. New York, Routledge, 2000.

. For More than One Voice Toward a Philosophy of Vocal Expression. Stanford, California, Stanford University Press, 2005.

DELEUZE, Gilles. Cinema 2: The Time-Image. Hugh Tomlinson \& Robert Galeta (Trans.) London, The Athlone Press, 1989.

DOANE, Mary Ann. The Voice in the Cinema: The Articulation of Body and Space. Yale French Studies, n. 60, Cinema/Sound, 1980, pp.35 [https://doi.org/10.2307/2930003 - accessed 18 May 2019]

FARINATI, Lucia \& Firth, Claudia. The Force of Listening. Berlin, Errant Bodies Press, 2017.

FELDMAN Marzochi, Ilana. Jogos de cena: ensaios sobre o documentário brasileiro contemporâneo. Ph.D Dissertation Estudos de Meios e da Produção Mediática. Universidade de São Paulo, São Paulo, 2012 [https:/www.teses.usp.br/teses/disponiveis/27/27153/tde22052013-110822/publico/lanaFeldmanMarzochi.pdf - accessed 18 May 2019].

GUIMARÃES, César. The scene and the Inscription of the Real. In: ANDERMANN, Jens and BRAVO, Álvaro Fernández (ed.). New 
Argentine and Brazilian Cinema Reality Effects. New York, Palgrave Macmillan, 2013, pp.87-101.

JAMES, Nick. Clio, Andrea and Lorraine too. Sight and Sound, vol. 20, Issue 11, November 2010, pp.25-6.

JOHNSTON, Claire. Women's Cinema as Counter Cinema. In: THORNHAM, Sue (ed.). Feminist Film Theory: A Reader. New York, New York University Press, 1999, pp.31-40.

JÚNIOR, Carlos Pernisa \& CARVALHO, Helena Oliveira Teixeira de. Jogo de cena: um outro olhar sobre a entrevista no documentário. Doc On-line, n. 22, September 2017, pp.28-47. DOI: 10.20287/doc.d22.dt02

KAPLAN, E. Ann. The Realist Debate in the Feminist Film: a Historical View of Theories and Strategies in Realism and the Avant-Garde. In: Women \& Film Both Sides of the Camera. London \& New York, Routledge, 2000, pp.125-141.

KUHN, Annette. Women's Pictures: Feminism and Cinema. London, Routledge and Kegan Paul, 1982.

LESAGE, Julia. The Political Aesthetics of the Feminist Documentary Film. In: ERENS, Patricia (ed.). Feminist Film Criticism. Bloomington and Indianapolis, Indiana University Press, 1999, pp.222- 237.

MARGULIES, Ivone. In Person: Reenactment in Postwar and Contemporary Cinema. New York, Oxford University Press, 2019.

MARTINEAU, Barbara Halpern. Talking about Our Lives and Experiences: Some Thoughts about Feminism, Documentary and "Talking Heads". In: WAUGH, Thomas (ed.). Show Us Life: Toward a History and Aesthetics of the Committed Documentary. Metuchen NJ, Scarecrow, 1984, pp.252-273.

MICHEL, Sonya. Feminism, Film, and Public History. In: ERENS, Patricia (ed.). Issues in Feminist Film Criticism. Bloomington and Indianapolis, Indiana University Press, 1990, pp.238-250.

MELLO, Cecília. Art and Reality in The Arbor. Acta Univ. Spaientiae, Film and Media Studies, no. 12, 2016, pp.115-128. DOI: 10.1515/ausfm-2016-0006. 
NEUMAN, Shirley. Autobiography and Questions of Gender. Portland, Frank Cass Publishers, 1991.

PAGE, Joanna. Beyond Reflexivity: Acting and Experience in Contemporary Argentine and Brazilian Cinema. In: ANDERMANN, Jens and BRAVO, Álvaro Fernández (ed.). New Argentine and Brazilian Cinema Reality Effects. New York, Palgrave Macmillan, 2013, pp.73-85.

PEIRSE, Alison. Speaking for herself: Andrea Dunbar and Bradford on film. Journal for Cultural Research, 20 (1), 2016, pp.60-72. [https://doi/org/10.1080/14797585.2015.1134060 - accessed 18 May 2019]

POLAN, Dana B. Brecht and the politics of self-reflexive cinema. Jump Cut, $\quad$ n. $1, \quad 1974$ [https://www.ejumpcut.org/archive/onlinessays/JC17folder/BrechtPola n.html - accessed 15 May 2019].

RICH, B. Ruby. Chick Flicks: Theories and Memories of the Feminist Film Movement. Durham and London, Duke University Press, 1998.

SAYAD, Cecilia. Performing Authorship Self-inscription and Corporeality in the Cinema. London \& New York, I.B. Taurus, 2013.

SMITH, Sidonie and Watson, Julia. Decolonizing the Subject: Politics of Gender in Women's Autobiography. Minneapolis, University of Minnesota Press, 1993.

WALDMAN, Diane and WALKER, Janet (ed.). Feminism and Documentary, Minneapolis and London, University of Minnesota Press, 1999.

XAVIER, Ismail. Character Construction in Brazilian Documentary Films: Modern Cinema, Classical Narrative and Micro-Realism. In: NAGIB, Lúcia and MELLO, Cecília (eds.). Realism and the Audiovisual Media. Basingstoke-Hampshire, Palgrave Macmilliam, 2009, pp.210-223.

XAVIER, Ismail. Inquires into Eduardo Coutinho and his Dialogue with Modern Tradition. Film Quarterly, vol. 69, n. 3, 2016, pp.35-43. [https://doi.org/10.1525/fq.2016.69.3.35]

XAVIER, Ismail. O Jogo de cena e as outras cenas. In: OHATA, Milton (ed.). Eduardo Coutinho. São Paulo, Edições Sesc, 2013, pp.604626. 